Letter

Circular

IC-57I

(Superseaing LC-485)

U.S. DEPARTMENT OF COMMERCE

NATIONAI BUREAU OF STANDARDS

WASHINGTON

October 3, 1939

Optical Instruments, Refractometry, and Optical Glass: Publications. 



\section{GENERAL INFORNATION}

The publications listed herein relate to a particular field of activity at the National Bureau of Standards. For other Government publications issued by this bureau, see Circular 24 and its supplements (the first three listed in Section III of this letter circular).

Articles that have been published by the U. S. Government may be consulted in various Government-depository libraries of which there are two or more in each state. Publications marked $O P$ are out of print and no longer available for distribution or sale. To obtain available publications, send orders with remittance to the Superintendent of Documents, Government Printing office, Washington, D. C. (DO NOT send orders to the National. Bureau of Staidards, except for Letter Circulars, which may be obtained upon application without charge.) The particular series to which a Government publication belongs is indicated by the initial letter preceding the number as follows:

$$
\begin{aligned}
& \text { C, Circular; } \\
& \text { LC, Letter Circular; } \\
& \text { S, Scientific Paper; } \\
& \text { RF, Research Paper. }
\end{aligned}
$$

In referring to wublications, the serial letter and the number are both needed to give complete identification, and both should be used in ordering (as, for examole, "National Bureau of Standards publication RP427"). Government publications from the Superintendent of Documents usually reach destinations within a 
week or two. For convenience of the general public coupons (good until used in exchange for Government publications) may be purchased from his office in sets of 20 for 1.00 .

Domestic remittances should be made by coupons, postal money order, express order, or ITew York draft payable to the "Superintendent of Documents, Government Printing Office, Washington, D. O." Postage stamps, defacec or smooth coins, or foreign money will not be accepted. Publications are forvarded under Government frank to adoresses in the United States and its possessions; also to Canada, Cuba, Mexico, Nevfoundland, and the Republic of Panama.

Remittances from foreign countries, with exception of those mentioned in tine preceding paragraph, should include in addition to the price of the publication, about one-third of the quoted price in order to cover postage. If the amount remitted exceeds postage requiremerts, the balance will be refunded; or if additional postage is required notification will be made. Renittances should be made by international money order or by New York draft.

In general, reprints of the articles which have appeared in scientific periodicals, other than those of the Government, are not available for distribution. Fany of the larger libraries maintain files of trese scientific journals and tiney may be readily consulted. Local libraries not having such files available, may be able to borrow desired oublications from a larger library. 


\section{LIST OF NON-GOVERNHEIT PERIODICALS}

Inquiries regarding the purchase of back numbers of magazisles containing any of the articles listed in section IT should be addressed to the publishers. For this purpose their adäresses are given in the list wich follows:

American Machinist, McGraw Fill Publishing Co.,

330 W. 42 nd Street,

New York, N.Y.

Annual Report of Compressed Gas Manufacturers Ass'n., Inc., Compressed. Gas linufacturers Ass'n., Inc.,

120 west Forty-secorid. Street,

New York, N.Y.

Army Ordnance,

The Arny Ordnance Association,

Mills Builaing,

17th st. and Pennsyivania Ave.,

Washington, D. C.

Astronomical society of the pacific,

$31 c^{\circ}$ Merchants Exchange Bldg.,

San Francisco, Calif.

Journal of the American Cerainic Society,

$2525 \mathrm{~N}$. High Street,

columbus, onio.

Journal of the Optica.l Society of America and Review of Scientific Instruments, American Institute of Physics,

175 Fifth Avenue,

New York, N. Y.

Nature,

St. Nartin's street,

London. W.C.2, England.

The Military Engineer,

Mills Building,

17th St. and Pennsylvania Ave.,

Washington, D, C.

National Geographic Nagazine,

l6th and N Streets, N.H.,

washington, D.C.

Photogrammetric Engineering,

724 Ninth street, N.N.,

Nashington, D. C. 
III. PUBLICATIONS ISSUED BY THE U.S. GOVERNAENT

Series Price

C24 $25 \mathrm{c}$.

Publications of the Bureau of Standards $1901-25$.

25c. Supplementary list of publications of the Bureau of Standards.

July 1, 1925- December 31, 1931.

5c. Supplementary list of publications of the National Bureau of Standards.

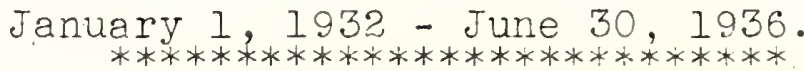

$C 27 \quad O P$

Testing and properties of optical instruments. Cir. BS, C27 (1918). 41 pp. 1 illus.

Cllo 5c. Specifications for marine sextants. Cir. BS, Cllo (1921). 8 pp.

C389 10c. Making of mirrors by deposition of metal on glass.

Cir. BS, $C 389$ (1931) 19 pp. 2 illus.

S110

$\mathrm{OP}$

New methoa for determining the focal length of a converging lens.

I.G. Priest.

B.S. Sci. Pap. $\underline{5}, 483(1908-09) 15 \mathrm{pp}$.

S122

OP

Resolving power of objectives.

P.G. Nutting.

BS. Sci. Pap., 6, $121(1909-10) 5$ pp. 1 illus.

$S 215$

$O P$

Micrometer miaroscopes.

A.T. Gray .

BS Sci. Pap., 10, 375 (1914) 16 pp. 3 illus.

S3l1 OP Axial aberrations of lenses.

E.D. Tillyer and H.I. Schultz.

BS Sci. Pap., 14, $341(1918-19) 29$ pp. 27 illus.

S333

$\mathrm{OP}$

Optical conditions accompanying the striae which appear as imperfections in optical glass.

A.A. Michelson.

BS Sci. Pap., 15, $41(1919-20) 5$ pp. 1 illus.

S358 OP Concerning the annealing and characteristics of giass.

A.Q. Tool and J. Valasek.

BS Sci. Pap., 15, 537 (1919-90) 35 pp. 10 illus. 
Series Price

S373 5c. Characteristics of striae in optical Elass. T.T. Smith, A.H: Bennett, and G.E. Nerritt. B.S. Sci. Pap., I6, 75 (1920) 18 pp. 19 illus.

S393 10c. Measurements of thermal dilation of glass at high temperatures.

BS Sci. Pap., 16, 449 (1920) 39 pp. 21 illus. C.G. Peters and C.H. Cragoe.

S46I OP Spherical aberration of thin lenses. T.T. Smith.

BS Sci. Pap., 18, 559 (19?2-23) 26 pp. 15 illus.

S485 5c. Application of the interferometer to measurements of the thermal dilation of ceramic materials G. E. Merritt. BS Sci.Pap., 19, $357(1923-24) 17 \mathrm{pp}$. 14 illus.

S494 OP Aberrations of lone focus anastigmatic photographic Ienses.

A. F. Bennett.

BS Sci. Pap., 19, 587 (1993-24) 54 po. 52 illus.

S5? I I0c. Measurements of the index of refrection of glass at high temperatures.

C.G. Peters.

BS Sci. Pap., 20, (1924-26) 25 p. 14 illus.

S550 OP Application of the algebraic aberration equations to opticel design.

I.C. Gardner.

BS Sci. Pap., 22, $73(1927-28) 131$ pp. 55 illus.

S572 10c. Cause and removal of certain heterogeneities in glass.

L.W. Tilton, A.N. Finn, and A.Q. Tool.

BS Sci. Pap., 22, $719(1927-28) 18$ pp. Il illus.

RP52 10c. Interference method for the determination of axial and oblique aberrations.

A. H. Bennett.

BS J. Research, 2, 685 (1929) 18 pp. II illus.

RP64 IOc. Prism refractometry and certain goniometrical requirements for precision.

L.W. Tilton.

BS J. Research, 2, 909 (1929) 22 pp. 2 illus.

RP71 5c. Determination of the source and means of prevention of stones in glass.

H. Insley.

BS J. Research, ?, 1077 (1999) 8 pp. 9 illus.

RP97 10c. Making the glass disk for a 70-inch telescope reflector.

A.N. Finn:

BS J. Research, 3, 315 (1909) 15 pp. 9 illus. 
Series Price

RPIO2 IOc. Representation of aberration diffraction effects by means of rotating sectors. A. H. Bennett.

BS J. Researcin, 2, 391 (1929) Spp. 4 illus.

RPII2 5c. Optical heterogeneity of a fused quartz disk. L. W. Tilton and A. 2 . Tool.

BS J. Research, 3, 619 (1929) 10po. 2 illus.

RP219 100. Dimensional changes caused in glass by heating cycles. A.Q. Tool, D. B. Lloyd, and G. E. Merritt. BS J. Research, 5, 627 (1930) 20pp 7 illus.

RP262 10c. Prism size and orientation in mininum deviation refractometry.

L. W. Tilton.

BS. J. Research, 6, 59 (1931) 18 po. 6 illus.

RP272 10c. Optical coincidence gage.

I. C. Gardner and F. A. Case.

BS J. Researcil, 6, 229 (1931) 9pp. 6 illus.

RP292 10c. Variations caused in heating curves of glass by heat treatment.

A.Q. Tool and C. G. Eichlin.

BS J. Research, 6, 523 (193i) 30pp. 11 illus.

RP316 5c. Lateral chromatic aberration of apochromatic microscope systems.

I. C. Cardner and F. A. Case.

BS J. Research, 6 , 937 (1931) 10pp. 3 illus.

RP320 5c. Index of refraction of some soda-lime-silica glasses as a function of the composition. C. A. Faick and A. IT. Finn.

BS J. Researcis, 6, 993 (1931) 10pp. 3 illus.

RP345 IOc. Restoration of solarized ultra-violet transmitting glasses by heat treatment.

A. Q. Tool and R. stair.

BS J. Fesearch, I, 357 (1931) 1spp. 5 illus.

RP4.27 5c. Optical requirements of airplane mapoing.
I. C.Gardner.

BS J. Research, 으, 445 (1932) Ilpp. 5 illus.

RP466 5c. Reciproeal spherical aberration of an optical system including higher orders.

Farold $\mathrm{F}$. Bennett.

BS J. Research, 2, 187 (1932) 39pp. 11 illus.

RP467 5c. Attachment for turning approximately spherical surfaces of small curvature on a lathe.

I. C. Gardner.

BS J. Research, 2, 227 (1932) 11 pp. 2 illus. 
Series Price

RP575 5c. Permissible curvature of prism surfaces and inaccuracy of collimation in precise minimumdeviation refractometry. L. T. Tilton. BS J.Research, 11, 25 (1933) 33 pp. 9 illus.

RP577 5c. Viscosity of optical glass.

W.H. Wadleigh.

BS J. Research, 11, 65 (1933) 14 pp. 6 illus.

RP626

5c. Effect of heat treatment on the expansivity of a pyrex glass.

J.B. Saunders and A. Q. Tool.

BS J. Research, 11, 799 (1933) I2 pp. I illus.

RP667

5c. Thermal expansions of some soda-lime-silica glasses as functions of the composition. B.C. Schmid, A.N. Finn, and J.C. Young. BS J. Research, I2, 421 (1934) 8 pp. 3 illus.

RP695

5c. Variations in refractive index of co2-free air and a statistical correlation with solar activity.

I.W. Tilton.

J. Research NBS 13, III (1934) 14 pp. 2 illus.

RP703

50. Refractive index and dispersion of normal and heavy water.

I.W. Tilton and J.K. Taylor.

J. Research NBS 13, 277 (1931) 3 pp.

RP762

50. Index of refraction, density, and thermal

expansion of some soda-alumina-siliea glasses as functions of the compasition.

C.A. Faick, J.C. Young, D. Hubbard and A.I. Finn.

$J$. Researoh NBS 14, 133 (1935) 5 pp. 4 illus.

RP776

5c. Standard conditions for pre ise prism refractometry.

I. W. Tilton.

J. Research NBS 14, 393 (1935) 26 pp. I illus.

RP919

5c. Thermal control in inimu-deviation refractometry and temperature coefficients for a meium flint elass. I.W. Tilton.

J. Researah NBS 17, 339 (1936) 12 pp. 5 illus. 
Series Price

RP934 5c. Accurate representation of refractive index of distilled water as a function of wavelength. I.v. Tilton.

J. Research NES 17, 639 (1936) 12 pp. 2 illus.

- RP971 5c. Accurate representation of the refractivity and density of distilled water as a function of' temperature.

I. T. Tilton and J.K. Taylor

J. Research NBS 18, ?05 (1937) 10 pp. 2 illus.

RP984 5c. Precision camera for testing lenses. Irvine C. Gardner and Frank A. Case. J. Research INBS 18, 449 (1937) 12 pp. 8 illus.

RP986 5c "Camera Iinish" at the race track. Irvine C. Garaner.

J. Research NBS 18, 467 (1937) 8 pp. 3 illus.

RPI003 10c. Compressibility of fused-quartz glass at atmospheric pressure. H. B. Emerson.

J. Research NBS 18, 683 (1937) 30 pp. 5 illus.

RPlO14 5c. Gases in some optical and other giasses.

C. Hahner, G.Q. Voigt and A.N. Finn.

J. Research'NBS 19, 95 (1937) 10 pp. 2 illus.

RP1085 15c. Refractive index and dispersion of distilled water for visible radiation, at temperatures 0 to $60^{\circ} \mathrm{C}$.

L.W. Tilton and J.K. Taylor.

J. Research NBS 20,419 (1938) 59 pp. 19 illus.

RPI177 10c. Relation of camera error to photogrammetric mapping.

I. C. Gardner.

J. Research NBS 22, 209 (1939) 30 pp. 6 illus.

RPI187 5c. Effect of the solubility of glass on the behavior of the glass electrode.

D. Hubbard, E.IF. Hamilton and A.N. Finn.

J. Research NBS 2?, 339 (1939) 12 pp. 7 illus. 
Series Price

RP1197 5c. Density of some soda-potash-sjlica glasses as a function of the composition.

J.C. Young, F.N. Glaze, C.A. Faick and A.N. Finn J. Rescarch NBS 22, 453 (1939) 12 pp. 5 illus.

RFI216 5c. Resolving power and aistortion of typical airplane-camera lenses.

F.E. Washor.

J. Research NBS 22, 729 (1939) 18 pp. 4 illus. 
: 
IV. PUBLICATIONS IN HOH-GOVERNATIT PERIODTUALS

Compound lens systems. T. Tomnsend Smiti.

J. Opt. Soc. Am.

1. No. $4, .113(1217)$

A quicutative deterrination of the reflection coefficients cf some metris. in the schumann region. I. C. tardner.

Astro.-Pnys.J. 45 , No. 1, 30 (1917).

Sci. Am. Suppl. 84, No. 2174, 140 (1917).

Optical glass. Heber D. Curtis.

Pub., Astronomical Soc. Pocific,

31. $150.180,77(1919)$.

Apparatus for the testing of binocular telescopes

T. Townsenci shith

J. Opt. soc; Ar. 2, 3, Nos. 3-6.

$76-90$ (1919).

The cemented telescope objective of bariun crom and flint. I. C. Gardner.

J. Opt. Soc. AH. 4, Mo. 5, 275 (1020).

The coincidence type of self-contained rang finder. I. C. Garciner.

J. Opt. soc. Am., 5, iJo. 5, 420 (I92I)

Constructional data for a cemented telescone objective of barium crown and flint. I. C. Gardner.

J. Opt. Soc. An. and Rev. sci. Inets.,

6, IT. 3, 379 (1922).

A field telemeter for approximate survujing.

I. C. Gardner.

J. Opt. Soc. Am. and Rev. Sci. Insts.,

6, No. 5, 489 (1922).

Certain effects produced by chilling glass A.Q.Tool.

J. Opt. Soc. Am. and Rev. Sci. Insts.,

s. $479(1924)$.

The standardization of optical fixe control instruments.

I. C. Gardner.

Army ordinance, 5, 512 (Sept. - Oct. 1924)

Image curvature as a function of diaprragm position.

I. C. Gardner.ind. J J. Arnaud.

J. opt. Sod. Am. and Rev. Sci. Insts.,

9, No. 6,675 . (1924)

Variations in glase aused oy reat tieatrent.A. a. Tool. J. Arí. ceranic Soc. S, I (Jonuary iga 5 ). 
A magnifying stereoscope and camera; two instruments for airplane mapping. I. C. Garaner.

J. Opt. Soc. Am. and Rev. Sci. Insts.,

11, No. 2, 195, (1925).

A modified Hartmann test based on interference.

I. C. Gardner.

J. Opts. Soc. Am and Rev. Sci. Insts.,

1.1, No. 4, 441, (1926).

A carere for ohotograpiing tie interior of a rifle barrel.

I. C. Gardner and F. A. Case.

J. Opt. Soc. Am; and Rev. Sci. Insts.,

12, $159(1926)$.

Regarding the heat treatment of glass and its refractivity and density. A. Q. Tool, I. W. Tilton, and E. E. Hill.

J. Opt. Soc. Am. are Rev. sci. Insts.,

12, No. 4 , 490 (1926).

An optical system for reading the angular deflection of a mirror. I. C. Gardner.

J. Opt. Soc. Am. ard Fev. Sci. Insts.

12, $529(1926)$.

Photographing the bore of a rifle. I. C. Gardner.

The military Enginetr, 18, 480 (1925).

Making a standard of planness. C. A. Skinnor. General Electric Rev.

29 No. 8, 528, (August 1926).

optical metnods for testing compressed gas containers. I. C. Gardner.

Fourtecnth Ann. Rep., Compressed Gas

Manufacturers' Assn. Inc., 24 (Tan. 1927).

The distortion of some typical nhotographic objectivas. A. I. Bennett.

J. Opt. Soc. Am. and Iet. Sci. Insts.,

14, No. 3, 235, (1927).

The jompensation of distortion in objectives for airplane photography. I. C. Gardiner and A. L. Bennett. J. Oot. Soc. An. and Rev. sci. Insts., 14, Io. 3, 245 (1927).

A modified Hartmann test based on interference. I. C.Gardner and A. Y. Bennett. (translated from paper in J. Opt. Soc. Am. and Rev. Soi. Insts. 1925)

Zeitschrift fur Irstrumentenkunde, 44, No. 47 , $[07,( \pm 9.7)$. 
Some effects of carefully annealing optical glass. L.W. Tilton, A.N. Finn, and A.Q. Tool.

J. Am. Ceramic Soc., II, No. 5, 292 (1928)

Variations in the optical density of glass. L.W. Tilton.

J. Wash. Acad. Sci., 20, No. 1, 12 (1930).

An optical coincidence gage.

I.C. Gardner.

$$
\text { Am. Machinist 74, No. 4, } 155 \text { (1931). }
$$

Spherical surfaces of slight curvatures.

I.C. Garaner.

Am. Machinist, 76, 994 (Sept. 1932).

Sunspot number and the refractivity of dry air. I.V. Tilton. Nature (London), 132, p. 855 (1933).

The interpretation and uses of lens tests and camera calibrations.

Irvine C. Gardner.

Photogrammetric Engineering 3, No. 1, 12 (1937).

Observing an eclipse in Asiatic Russia.

Irvine C. Gardner.

National Geographic Vagazine 71, 179 (1937).

Specifications for a precision mapping camera. Irvine C. Gardner.

Photogrammetric Engineering 4, No. 3, 173 (1939).

Corona photography during the eclipses of 1936 and 1937. Irvine C. Gardner. National Geographic Society Technical Papers, Solar Eclipse Series No. 1, 39 (1939). 
